Agro-Science Journal of Tropical Agriculture, Food, Environment and Extension Volume 14 Number 1 January 2015 pp. 31 - 36 ISSNIII9-7455

\title{
EXTENSION NEEDS IN QUAIL FARMING IN IMO STATE, NIGERIA
}

\author{
Iwuchukwu, J.C, Nwobodo, C.E and Owunta, S \\ Department of Agricultural Extension, \\ University of Nigeria Nsukka, Enugu State, Nigeria. \\ E-mail Juliana.iwuchukwu@unn.edu.ng and julieiwuchukwu@yahoo.com
}

\begin{abstract}
The study ascertained extecisin needs in quail faming in Imo State, Nigeria. Simple random sampling technique was used to select two agricultural zones (Owerri and Orlu zones) while proportionate sampling technique was used to select about $50 \%$ of extension personnel in the two zones. Thus, a total of 73 respondents were used for the study. Data were analysed with percentage and mean score. Greater proportion (54.8\%) of the extension staff used in this study were extension agents who were females $(52.1 \%)$ and had first degree education (60.3\%). Their mean age and mean years of experience in extension work were $45.3 y e a r s$ and 13.8 years respectively Respondents had no good source/s of information on quail hence their perceptions show that they are not knowledgeable about the economic and nutritional importance of quail. One of the areas they needed training in quail was importance of quail"(79.5\%) while one of the major challenges of quail faming is "lack of access to information on how to rear quail" $(M=2.71)$.The study recommended the need to boost research on quail production so that extension workers, farmers and consumers will appreciate the importance of this livestock and enjoy it"s nutritional and economic benefits.
\end{abstract}

Key words: extension needs quail farming Imo State

\section{INTRODUCTION}

In recent times, there has been a significant shortfall between the production and supply of animal protein to feed the ever increasing human population. Nigeria at present with a population of over 140 million people is expected to contribute a significant percentage of anticipated population growth in sub-Saharan Africa. Notwithstanding, Nigeria is highly deficient in animal protein security with per capita consumption put at $9.3 \mathrm{~g} /$ day as against the $34 \mathrm{~g} /$ day which is the FAO recommended minimum requirement for growth and development of the body (Ojo and Ikhelao, 2008 in Owen and Dike, 2013).

The growing need for sources of meat for the purpose of human consumption led to the occurrence of extraordinary developments in the production of animal protein especially white meat (FAO, 2010). The increase of the growing need for the white meat encouraged the poultry industry and expands the breeding and improving the taming of birds in order to get benefit of their meat and eggs (Hammeed and Ahmed, 2012). The Japanese quail was introduced to Nigeria in 1992 (NVRI, 1994 in Daikwo et al., 2011). The purpose for the introduction was to diversify the poultry sub-sector and help supplement domestic chicken production through massive quail farming. Since then, quail farming has been growing in Nigeria (Daikwo, Dim, and Momoh, 2011)

Quails are very small sized poultry bird requiring minimum floor space and their rearing system is very easy and simple (RoysFarm, 2014). Quails reach sexual maturity early as layer quails start laying eggs within six to seven weeks of age. They have high egg laying rate as a layer quail can lay up to 280 eggs per year (RoysFarm, 2014). The initial investment in quail farming is relatively low and they reach marketing age quite earlier (within 5 weeks of age).

Quails are produced mainly for their eggs and meat. It has high protein content and a relatively low fat content in terms of lipids; it has slightly more undesired saturated fats (Ani and Emeh (2009). However, it also has a higher content of the good polyunsaturated fatty acids. It is a significant source of phosphorus, iron and copper, while providing reasonable amounts of zinc and selenium. Vitamin-wise, it has high niacin (vitamin B3) and pyridoxine (vitamin B6) content. So, it has either the same or substantially 
higher amounts of minerals and vitamins when compared to broilers (www.Nutridata.self.com).

Quail eggs have positive effects on people with stress problems, hypertension, digestive disturbance, gastric ulcer, liver problems, blood pressure, migraine, asthma, anaemia, various types of allergies, eczema, heart problems, bronchitis illnesses, depression, panic and anxiety illnesses. Quail eggs are also known to stimulate growth, increase sexual appetite, stimulate brain functions which improves intelligence quotient and generally rejuvenates the body (www.quail farm.co.uk). Currently, quail production does not seem to be experiencing much substantial and sustained growth, despite its attractive medicinal and economic features. In Nigeria, and specifically in Imo State, only very few people engage in quail farming. This may suggest a dearth in knowledge of the huge economic, nutritional, and medicinal benefits of quail among farmers and other stakeholders in agriculture especially agricultural extension agencies. Subsequently, creation of awareness and consequent development of quail farming technology for dissemination to farmers may be hampered. Ascertaining perception/ knowledge and training needs of extension personnel in quail farming will $\mathrm{x}$-ray gaps that need to be addressed in order to make them ready and better equipped to undertake tasks associated with the enterprise and agriculture in general with trickledown effect on farmers and other stakeholders.. Specifically, the study sought to:

1. Identify sources of information on quail farming among extension staff;

2 ascertain perceived importance of quail identify training needs of extension personnel on quail farming and

3. ascertain challenges of quail farming .

\section{MATERIALS AND METHODS}

The study was carried out in Imo State, Nigeria. All extension workers in the State Agricultural Development Programme (ADP) constituted the population for the study. Out of the three agricultural zones in the State, two zones (Owerri and Orlu zones) were randomly selected and proportionate sampling technique was used to select 73 (about 50\%) extension staff in the two zones Data were collected using questionnaire.

Respondents' age and length of service were captured in years, sex was captured as male or female and cadre as Programme Manager(PM), Zonal Extension Officer (ZEO), Subject Matter Specialist (SMS)etc. Their educational qualification was measured as General certificate in Education (GCE), Ordinary National Diploma (OND) among others. Respondents were requested to indicate their sources of information on quail farming. Some of the sources provided were fortnightly training ( FNT), radio, fellow extension workers, Monthly training review meeting (MTRM), etc. Perceived importance of quail was ascertained using a 3-point Likert type scale of strongly agree (3), agree (2) and disagree (1) with a cut-off point of 2 . Such that variables with mean scores of 2 and above were regarded as importance of quail while those with mean scores less than 2 were regarded otherwise. Among the variable measured were quick return on investment, low initial capital, stimulate brain function, treatment of ulcer. Respondents also indicated areas they needed training on quail production/farming which included feeding, housing, breeding of snail etc. Challenges of quail farming were ascertained using three point Likert-type scale of to no extent (1), little extent (2), and to great extent (3) with 2 as decision point. Variables with mean scores of 2 and above were regarded as challenges while those with mean scores less than 2 were regarded otherwise Some of the variables measured include: lack of training, poor funding of ADP, lack/ low access to information on quail etc.

\section{Data Analysis}

The socio-economic characteristics of the respondents were presented using percentage and mean score. Objectives 1 and 3 were presented using percentage while objectives 2 and 4 , were presented using mean score.

\section{RESULTS AND DISCUSSION}

Socio economic characteristics of respondents

Table 1 shows that greater proportion (33.1\%) of the respondents were between the age of 35-39 years. Their mean age was 45.3 years indicating that the respondents were at their active productive age. Majority $(52.1 \%)$ of the respondents were female while $47.9 \%$ were male.

Entries in Table 1 show that greater proportion $(40.6 \%)$ of the respondents had worked for 9-15 years in Imo State ADP. The mean length of service was 13.8 years. This shows that respondents were moderately experienced in agricultural extension work. Majority $(54.8 \%)$ of the respondents were field extension agents (EAs) while block extension supervisor (BES) accounted for $15.1 \%$. Subject Matter Specialist (SMS) accounted for $12.3 \%$, block extension agent (BEA) accounted for 9.6\%, while $2.7 \%$ each accounted for Program manager (PM) Zonal manager, and Zonal extension officer. Majority $(60.3 \%)$ of the respondents had first degree, $31.5 \%$ had OND, $4.1 \%$ had masters degree, while $4.1 \%$ had GCE certificate. These indicate that the respondents were literate and are therefore likely to discharge their extension work effectively. 
Extension Needs in Quail Farming in Imo State, Nigeria

Table 1: Distribution of respondents according to socio-economic characteristics

\begin{tabular}{lll}
\hline Variables & Percentage & Mean \\
\hline Age & & \\
$35-39$ & 33.1 & 45.3 \\
$40-44$ & 26.1 & \\
$45-49$ & 22.0 & \\
$50-54$ & 16.4 & \\
$55-59$ & 2.4 & \\
Sex & 47.9 & \\
Male: & 52.1 & \\
Female: & & \\
Length of service & 15.4 & \\
Less than a year & 30.0 & \\
1-8years & 40.6 & \\
9-15years & 9.8 & \\
16-23years & 4.2 & \\
24-28years & & \\
Cadre: & 2.7 & \\
PM & 2.7 & \\
ZM & 2.7 & \\
ZEO & 12.3 & \\
SMS & 15.1 & \\
BES & 9.6 & \\
BEA & 54.8 & \\
EA & 4.1 & \\
Highest level of education & 31.5 & \\
GCE & 60.3 & \\
OND & 4.1 & \\
First degree & & \\
Master & &
\end{tabular}

Sources of information on quail farming

Table 2: Sources of information on quail

\begin{tabular}{ll}
\hline Sources of information & Percentage \\
\hline FNT & 6.80 \\
Radio & 8.20 \\
Fellow extension workers & 16.40 \\
Ministry of agriculture & 2.70 \\
Workshop/seminar & 16.40 \\
Newspaper & 8.20 \\
Friends and relatives & 2.70 \\
Family members & 4.10 \\
Internet/computer & 11.00 \\
Self initiative & 13.9 \\
Research institutes & 9.60 \\
\hline
\end{tabular}

Table 2 shows that respondents did not have multiple sources of information and their sources of information on quail varies among them. About $16.4 \%$ of the respondents indicated fellow extension workers, another $16.4 \%$ indicated workshop/seminar/training while $13.9 \%$ and $11.0 \%$ indicated self initiative and internet/computer respectively as their sources of information on quail. Other sources of information on quail as indicated by the respondents were research institutes ( $8.2 \%)$, radio $(6.8 \%)$, fortnightly training (FNT) $(6.8 \%)$, family members $(4.1 \%)$, and ministry of agriculture $(2 . .70 \%)$. This implies that respondents are yet to have good quail farming information from multiple and reliable sources which will boost their interests and activities on quail enterprise

Perceived importance of quail Judging from the decision point of 2 and above, extension workers did not perceive any variable in the table as either economic or health/ medicinal importance of quail. Some of the factors that were not perceived as economic importance of quail were : its resistance to diseases $(M=1.56)$, little capital for starting the business $(\mathrm{M}=1.51)$, while those that were not perceived as health medicinal importance of: quail were calcium contents easy to assimilate $(\mathrm{M}=1.37)$, vitamin $\mathrm{B} 3$ (niacin) and vitamin B6 (pyridoxine) content $(\mathrm{M}=1.37$ ), sufficient source of iron, copper, zinc, and selenium $(M=1.36)$, may accelerate recuperation after blood stroke and help strengthen heart muscles( $\mathrm{M}=1.34)$ among others. The findings tend to suggest that despite the benefits of quail production extension agent are not aware or knowledgeable of these facts probably due to lack of information on quail. It is also likely that quail production has not been incorporated into their programme. This points at the needs of these personnel with respect to quail production. 
Table 3 Mean distribution of respondents according to perceived importance of quail

\begin{tabular}{|c|c|c|}
\hline Benefits & Mean & STD \\
\hline \multicolumn{3}{|l|}{ Economic benefits } \\
\hline Higher resistance to diseases & 1.56 & 0.799 \\
\hline Lower initial capital & 1.51 & 0.748 \\
\hline High egg production & 1.48 & 0.748 \\
\hline Generation of higher income & 1.41 & 0.723 \\
\hline Short generation interval & 1.40 & 0.702 \\
\hline High returns within a very short time & 1.38 & 0.608 \\
\hline It requires small space for rearing & 1.38 & 0.608 \\
\hline Require little/cheap feeds & 1.38 & 0.700 \\
\hline Easy to rear/maintain & 1.37 & 0.697 \\
\hline \multicolumn{3}{|l|}{ Health/medicinal benefits } \\
\hline Contain important quality of calcium easy to assimilate & 1.37 & 0.717 \\
\hline Its contain vitamin $\mathrm{B} 3$ (niacin ) and vitamin B6(pyridoxine) & 1.37 & 0.717 \\
\hline Sufficient source of iron, copper, zinc and selenium & 1.36 & 0.695 \\
\hline High contents of good polysaturated fatty acids & 1.34 & 0.671 \\
\hline $\begin{array}{l}\text { May accelerate recuperation after blood stroke and help in } \\
\text { strengthening heart muscles }\end{array}$ & 1.34 & 0.711 \\
\hline Help to restore fertility/ potency in human being & 1.33 & 0.668 \\
\hline $\begin{array}{l}\text { Contain ovomucoid protein, used in the production of anti-allergic } \\
\text { drugs }\end{array}$ & 1.33 & 0.708 \\
\hline Help in treatment of panic and anxiety & 1.33 & 0.664 \\
\hline Help in healing gastritis ulcer & 1.30 & 0.664 \\
\hline Help inhibit cancerous growth & 1.30 & 0.660 \\
\hline Help eliminate and remove stones from liver, kidney and bladder & 1.30 & 0.701 \\
\hline Help in the treatment of tuberculosis & 1.29 & 0.656 \\
\hline Help in treatment of diabetes & 1.29 & 0.634 \\
\hline Stimulate intellectual abilities & 1.29 & 0.677 \\
\hline Increase hemoglobin level, remove heavy metals toxic from blood & 1.27 & 0.657 \\
\hline Help in treatment of asthma & 1.26 & 0.624 \\
\hline
\end{tabular}

Table 4: Distribution of respondents according to areas of training needs

\begin{tabular}{ll}
\hline Areas of training needs* & Percentage \\
\hline Identifying and acquiring good species & 75.3 \\
Housing & 78.1 \\
Breeding & 78.1 \\
Brooding and caring & 78.1 \\
Feeding & 76.7 \\
Provision of water & 78.1 \\
Characteristics/behavior & 78.1 \\
Importance & 79.5 \\
Incubation & 78.1 \\
Marketing & 78.1 \\
\hline
\end{tabular}

*multiple responses

Challenges of quail farming

\section{Areas of training needs of extension staff on quail farming}

Table 4 shows areas of training needs of extension personnel on quail farming to include: importance of quail $(79.5 \%)$, marketing of quail (78.9\%), brooding and caring for the young ones (78.1\%), provision of water $(78.1 \%)$, housing/equipment for rearing quail $(78.1 \%)$, preservinaral of quail (78.1\%), breeding of quail (78.1\%), characteristics/ behavior of quail (78.1\%), incubation and hatching of quail (78.1\%), feeding of quail (76.7\%), identifying and acquiring good species of quail (75.3\%). These findings have exposed the training needs of the personnel that need to be addressed in order to boost quail enterprise in the state and the country at large. Unfortunately, one of the problems faced by extension workers in Nigeria is lack of training opportunities (Agbamu (2005). Table 5 shows that respondents perceived all the variables in the table as constraints to quail farming. Prominent among them are: no access to information on how to rear quail $(\mathrm{M}=2.71)$, lack of well defined program on quail $(\mathrm{M}=2.70)$, lack of adequate funding of ADP by the government to undertake specific task like quail (M 
Extension Needs in Quail Farming in Imo State, Nigeria

Table 5: Mean distribution of respondents according to challenges of quail farming

\begin{tabular}{lll} 
Challenges & Mean & Std Deviation \\
\hline Lack of access to information on how to rear the birds & 2.71 & 0.70 \\
Lack of well defined program & 2.70 & 0.27 \\
Lack of adequate funding of ADP & 2.66 & 0.73 \\
Lack of training & 2.66 & 0.73 \\
Chicken are valued more than quail & 2.59 & 0.78 \\
Poor/low demand for the bird & 2.58 & 0.78 \\
The eggs are small and not attractive & 2.58 & 0.78 \\
Lack of access to feed & 2.55 & 0.82 \\
Inadequate research on quail & 2.53 & 0.84 \\
Lack of access to the birds & 2.53 & 0.78 \\
Quails are not presentable for ceremonies, festival and as gift & 2.53 & 0.78 \\
Susceptibility of the birds to infectious diseases & 2.53 & 0.80 \\
Its cannibalism nature(pecking) & 2.38 & 0.97 \\
Poor training on quail during MTRM & 2.34 & 0.93 \\
Poor training on quail during FNT & 2.34 & 0.95 \\
Heavy workload/ inadequate number of extension workers in the & 2.27 & 0.96 \\
system & & \\
Poor remuneration of extension workers to motivate them into & 2.14 & 0.99 \\
checking and adding new animal like quail in their program & & \\
\hline
\end{tabular}

= 2.66), lack of training on quail $(\mathrm{M}=2.66)$, chicken are valued more than quail $(\mathrm{M}=2.59)$, poor/ low demand for quail $(\mathrm{M}=2.58)$, quail eggs are small and unattractive (2.58), lack of access to feed $(M=2.55)$, inadequate research on quail production $(\mathrm{M}=2.53)$, lack of access to the birds $(\mathrm{M}=2.53)$ and susceptibility of quail to infectious diseases $(\mathrm{M}=2.53)$. Thus standard deviation is less than 1 for each of the variables in the table indicating uniformity in the responses of these respondents and usefulness of this data for policy. Agbamu (2005) opined that agricultural development system in Nigeria generally faced the problem of insufficient funds, limited number of trained human resources, lack of training opportunities, inappropriate salary scales and promotional prospects. Which may increase challenges that confront livestock business in Nigeria. These challenges also constrained quail production.

\section{CONCLUSION/ RECOMMENDATIONS}

The study has shown that although the extension staff are relatively young, literate with moderate experience in agricultural extension work they are yet to know more about quail. Hence tbe need to incorporate quail farming into the programme of ADP. Government and non-governmental organizations should then provide extension staff with opportunities for formal and informal training in emerging areas of agriculture like quail farming. Through the training they will acquire knowledge, skill and competence to handle issues related to quail business and disseminate such to farmers
There is need to boost research on quail production especially in improving the breed and developing good management practices. In this way extension workers and their clients (farmers) will appreciate the importance of this livestock and may domesticate this animal for nutritional and economic purposes.

\section{REFERENCES}

Agbamu J.U (2005). Problems and prospects of agricultural extension services in developing countries: in S.F Afolayan (Ed). Agricultural Extension in Nigeria. ARMTI, Ilorin. AESON. Vol 12:pp.5262.

Ani, A.O. Emeh, M.B. (2009). Response of growing Japanese quail (Cortunix Cortunix japonica) chicks to diets containing different energy and protein levels. Proceedings of the $34^{\text {th }}$ Annual Conference of the Nigerian Society for Animal Production, 15-16 ${ }^{\text {th }}$ march, 2009, Uyo. Pp 328-331.

Daikwo S. I. Dim N. I. and Momoh M. O. (2011) Hatching characteristics of Japanese quail in tropical environment. International Journal of Poultry Science. 10 (11).: 876-878 
FAO (2010). Poultry meat and eggs Agricbusiness Handbook. Director of investment center division FAO. Rome, Italy.

Hammeed R. A. and Ahmed A. A. (2012). Field and applied study to evaluate the economic and technical benefit of assumption project of quail breeding in Anbar Governorate. International Journal of Advanced biological Research. 2 (2): 358-362
National Research Council (1991). Microlivestock : little known small animals with promising future by panel of microlivestock Affairs, policy and global affairs, national research council national academic press 1 Jan 1991 technology and engineering 4300 pages.

Owen and Dike (2013). Japanese quail (Coturnix coturnix japonica) Husbandry: A means of increased animal protein base in developing countries. Journal of Environmental Issues and Agriculture in Developing Countries. 5 (1): 1-4

RoysFarm (2014). Quail farming in India.Available

at:http://www.roysfarm.com.www.Nutri data.self.com assessed 